\title{
Species richness and origin of the bryophyte flora of the Colombian Andes*
}

\author{
S. R. GRADSTEIN, G. B. A. VAN REENEN and D. GRIFFIN III
}

Institute of Systematic Botany, University of Utrecht, Heidelberglaan 2, Utrecht, The Netherlands and $\ddagger$ Florida Museum of Natural History, Gainesville, Florida, USA

\section{SUMMARY}

\begin{abstract}
Based on data from the ECOANDES project, a phytogeographical analysis has been made of the bryophyte flora along the wet, foggy western slope (1000-4500 m) and the drier eastern slope (500-4500 m) of the Colombian Central Cordillera at the 'Parque de los Nevados'. Species richness increases with altitude to the upper montane forest, which holds the largest diversity. Liverworts outnumber mosses in the upper submontane and montane forests on the western slope, but elsewhere, in drier environments, their number is lower and falls to below that of mosses. Furthermore, it appears that at lower altitudes, below $3000 \mathrm{~m}$, wide-ranging tropical species prevail whereas narrowranging tropical species (andean and endemic element) and species of temperate origin are more common at higher altitudes. Temperate species are relatively few, however, and attain less than $10 \%$ in the upper montane forest and about $20 \%$ in the páramo. They should have arrived in Colombia in the last 5 million years after the upheaval of the cordilleras.
\end{abstract}

Key-words: phytogeography, species richness, altitudinal zonation, Andes, bryophytes.

\section{INTRODUCTION}

Colombia, with its extensive and complex cordilleran system, may well hold one of the richest bryophyte floras of tropical America. Although collecting of mosses and liverworts has occurred in that country since the beginning of the 19th century, knowledge of the Colombian bryophyte flora is, at best, sketchy (Griffin \& Gradstein 1982). About 1500 species in 300 genera are recorded (Florschütz-de Waard \& Florschütz 1979; Gradstein \& Hekking 1979), but these numbers should be adjusted for new synonymy resulting from revision of taxonomically poorly known groups (e.g. Allen 1987; Grolle 1988) and for new records resulting from ongoing exploration (e.g. Van Reenen et al. 1984; Linares 1986; Sastre-de Jesús et al. 1986; Churchill \& Hollaender 1988; Wolf 1989). We would expect that the number of species will not increase following these adjustments.

In the framework of the ECOANDES project (van der Hammen et al. 1983; van der Hammen \& Ruiz 1984; Frantzen \& Bouman 1989) a study was made of the distribution

This paper is dedicated to Professor Dr T. van der Hammen on the occasion of his 65th birthday.

*Studies on Colombian cryptogams XXXIX.

Correspondence: Dr S. R. Gradstein, Institute of Systematic Botany, University of Utrecht, Heidelberglaan 2 , 3584 CS Utrecht, The Netherlands. 
and ecology of mosses and liverworts found along altitudinal transects through the Eastern, Central and Western Cordillera and on the north slope of the Sierra Nevada de Santa Marta. The investigation resulted in the recognition of five altitudinal bryophyte zones (Van Reenen \& Gradstein 1983, 1984; Van Reenen 1987), each characterized by floristic differences (bryophyte species composition) and by differences in total bryophyte mass (expressed as percentages cover) correlated with differences in macroclimate occurring along the gradient. These zones coincide more or less with the local altitudinal zones proposed for flowering plants (Cuatrecasas 1958; Cleef personal communication) and, furthermore, correspond very well with altitudinal bryophyte zonations recently recorded from the Andes of Peru (Gradstein \& Frahm 1987) and from Mt Kinabalu, Borneo (Frahm personal communication). The bryophyte zonation recognized is as follows; altitudinal boundaries given are averages and may vary due to local climatic conditions or human interference.

1. Tropical lowland forest $(c .0-500 \mathrm{~m})$. This zone is usually lacking in the ECOANDES transects.

2. Lower tropical submontane forest (c. 500-1200 m).

3. Upper tropical submontane forest (c. 1200-2200 m).

4. Lower tropical montane forest (c. 2200-3000 m).

5. Upper tropical montane forest (c. $3000-3700 \mathrm{~m})$.

6. Tropical alpine zone or páramo (c. $3700-4700 \mathrm{~m})$.

The zonation study clearly demonstrated that bryophytes may be excellent indicators of altitudinal zones in tropical mountain systems.

Other characteristic features of the flora of mountain systems include changes in species richness and phytogeographical composition with increasing elevation. For Andean vascular plants this has been discussed in detail by Gentry (1982) and Van der Hammen \& Cleef (1986); very little information has been available for bryophytes, however (Gradstein \& Pócs 1989). The purpose of the present paper is to examine this subject based on the ECOANDES data. We have restricted our analysis to the flora along the Central Cordillera transect (TPN) since this is the area for which the most complete data set is available at present.

\section{MATERIALS AND METHODS}

The location and altitudinal bryophyte zonation of the Central Cordillera transect (TPN) are shown in Fig. 1. The transect runs from the Cauca river along the rio Otun up to the páramo de Santa Rosa (Dept. Risaralda), across the Parque de Los Nevados and downwards along the río Totarito to the río Magdalena (Dept. Tolima). The western exposed slope, bordering the Cauca river valley, is foggy and wet and the eastern exposed slope bordering the Magdalena river valley is less foggy and therefore drier.

Bryophytes were sampled along the altitudinal gradient at 200-m intervals in plots laid out in the zonal vegetation, varying in size from $50-100 \mathrm{~m}^{2}$ (páramo), c. $250 \mathrm{~m}^{2}$ (highmontane forest) to $c .500 \mathrm{~m}^{2}$ (other forests). The plot sizes correspond with minimum areas of the various ecosystems (Cleef, personal communication).

In the forest plots collecting was only done in the lower understory $(0-3 \mathrm{~m}$ high). The bryophyte flora of the upper portion of the trunks and of the forest canopy, which has been the subject of a sequel study by Wolf and his students (Wolf 1989), has not been taken into consideration in this analysis. About 1700 collections of bryophytes were made in the plots (some further collecting was done outside the plots, for comparison). Following 


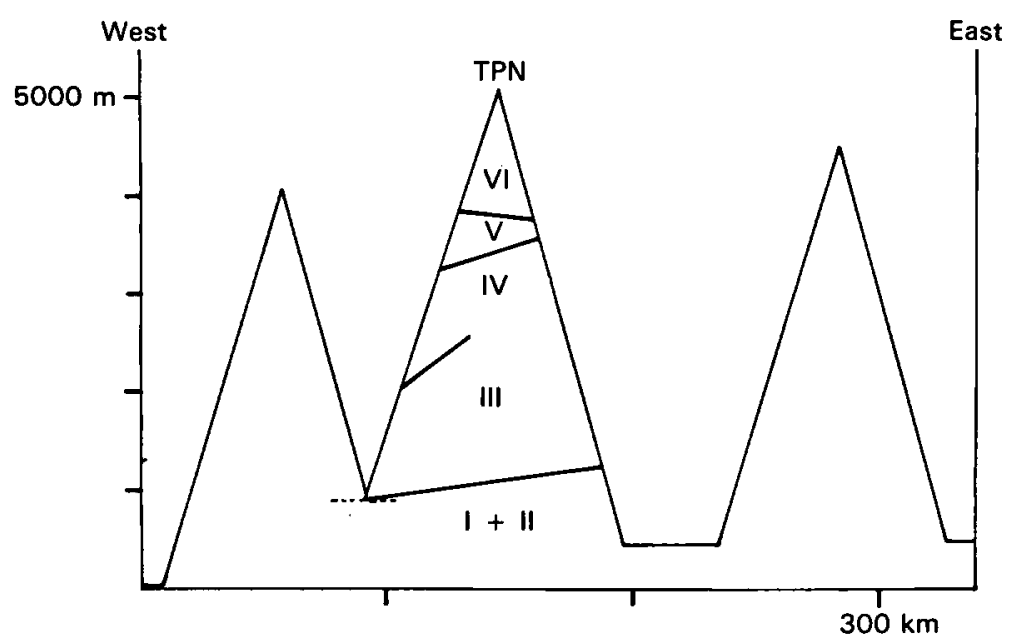

Fig. 1. Cross-section through the three Colombian cordilleras in the area of the ECOANDES studies, showing the TPN transect and the altitudinal zonation as defined by bryophytes. Notice the differences in zone boundaries between the (wet) western slope and the (dry) eastern slope.

species identification, the altitudinal bryophyte zonation was determined with methods described earlier (Van Reenen \& Gradstein 1983, 1984). For the purpose of the phytogeographical analysis geographical elements have been recognized based on the present ranges of species. Only species are used because the ranges of the higher bryophyte taxa (e.g. genera) are generally too large to be meaningful for our purpose. The analysis was based on about 350 species. Species for which a final identification was lacking have been excluded. The full list of species analysed is omitted here for space limitations.

\section{RESULTS AND DISCUSSION}

\section{Species richness}

Plot sampling along the two slopes of the TPN transect in the Colombian Central Cordillera (páramo and forest understory) yielded 25 species of mosses and liverworts in zone II, 256 species in zones III and IV (one figure is given for zones III and IV together because a distinction between these zones could not be made on the eastern slope), 195 species in zone V, and 53 species in zone VI (Fig. 2). It appears that the largest numbers of species are found between 1200 and $3800 \mathrm{~m}$ (zones III-V), whereas relatively few species are present below or above these altitudes. The very low number of species found below $1200 \mathrm{~m}$ (zone II) is probably due to the fact that this zone was not present on the western slope. Species numbers increase with altitude to zone $\mathrm{V}$ which holds the largest diversity in terms of species richness (Fig. 3). Moreover, it appears that liverworts are more numerous than mosses in zones III-V, whereas mosses outnumber liverworts in zones II and VI (Figs 2 and 3). The species richness figures correspond with biomass figures (cover percentages) recorded for liverworts and mosses (Van Reenen 1983).

The dominance of liverworts over mosses in zones III-V and their lower number in zones II and VI may be explained by the increased humidity (especially due to fog) in zones III-V, liverworts in general being more sensitive to drought than mosses. As humidity conditions differ considerably on either side of the cordillera due to differences in the frequency of mist, we have also compared the numbers and percentages of liverwort 


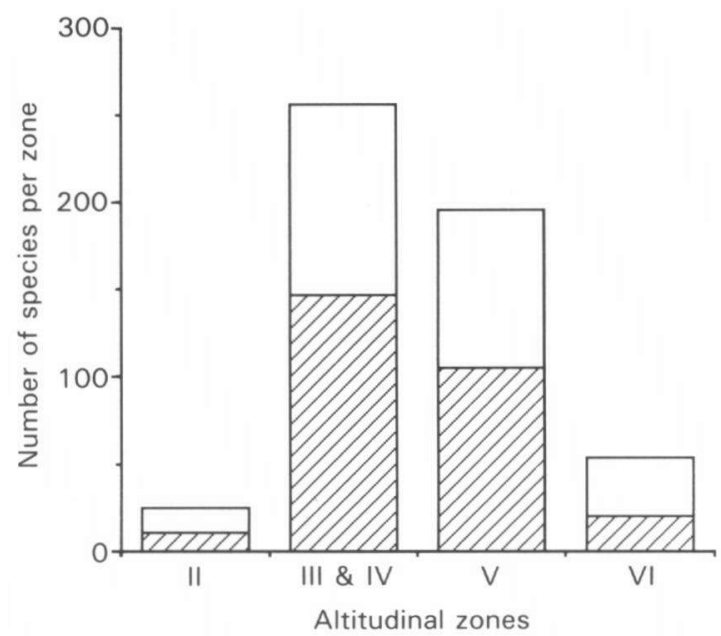

Fig. 2. Species richness of mosses (Musci; $\square$ ) and liverworts (Hepaticae; $\square$ ) in relation to the altitudinal bryophyte zones along the TPN transect. Zone I is lacking and zone II is only present on the eastern slope. Only one figure is given for zones III and IV as a distinction between these two zones could not be made on the eastern slope.

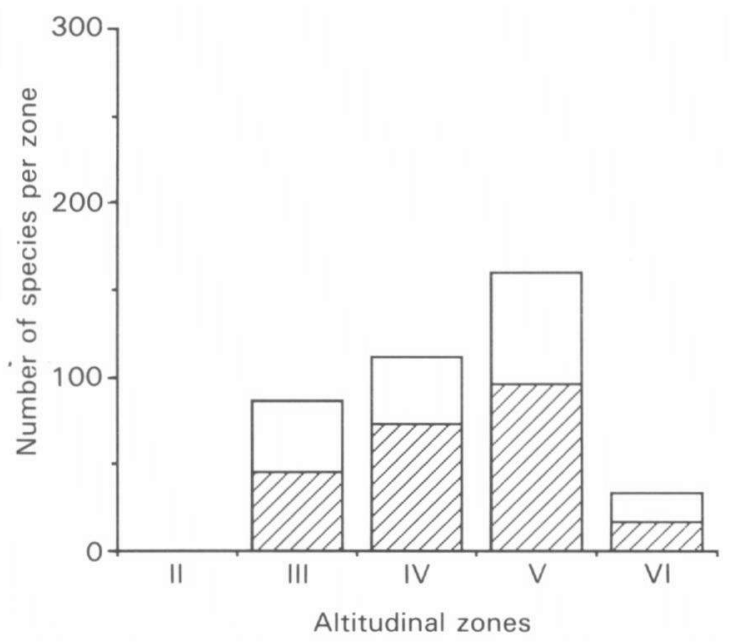

Fig. 3. Species richness of mosses (Musci; $\square$ ) and liverworts (Hepaticae; in relation to the altitudinal bryophyte zones on the (wet) western slope of the TPN transect. Zones I and II are lacking on this slope.

species and of moss species in the upper montane forest (zone V) on each slope (Table 1). The figures indicate that liverworts in fact outnumber mosses only on the very wet western slope of the cordillera. On the drier eastern slope their number is lower and falls below that of mosses. These data support the hypothesis that moss and liverwort diversities are humidity-dependent.

\section{Phytogeography}

The geographical elements recognized are the following.

1. Endemic element (Fig. 4a and b). Includes species restricted to the northern Andes: Ecuador, Colombia, Venezuela, e.g. Plagiochila cleefi, Riccardia pallida, Chaetocolea 
Table 1. Numbers and percentages of species of liverworts and mosses recorded in the upper montane forest on the (wet) western slope and on the (dry) eastern slope of the TPN transect, Colombia

TPN west $(3000-3750 \mathrm{~m})$

TPN east $(3300-3750 \mathrm{~m})$

$\begin{array}{lll}\text { Liverworts } & 96(60 \%) & 24(37 \cdot 5 \%) \\ \text { Mosses } & 64(40 \%) & 40(62 \cdot 5 \%)\end{array}$
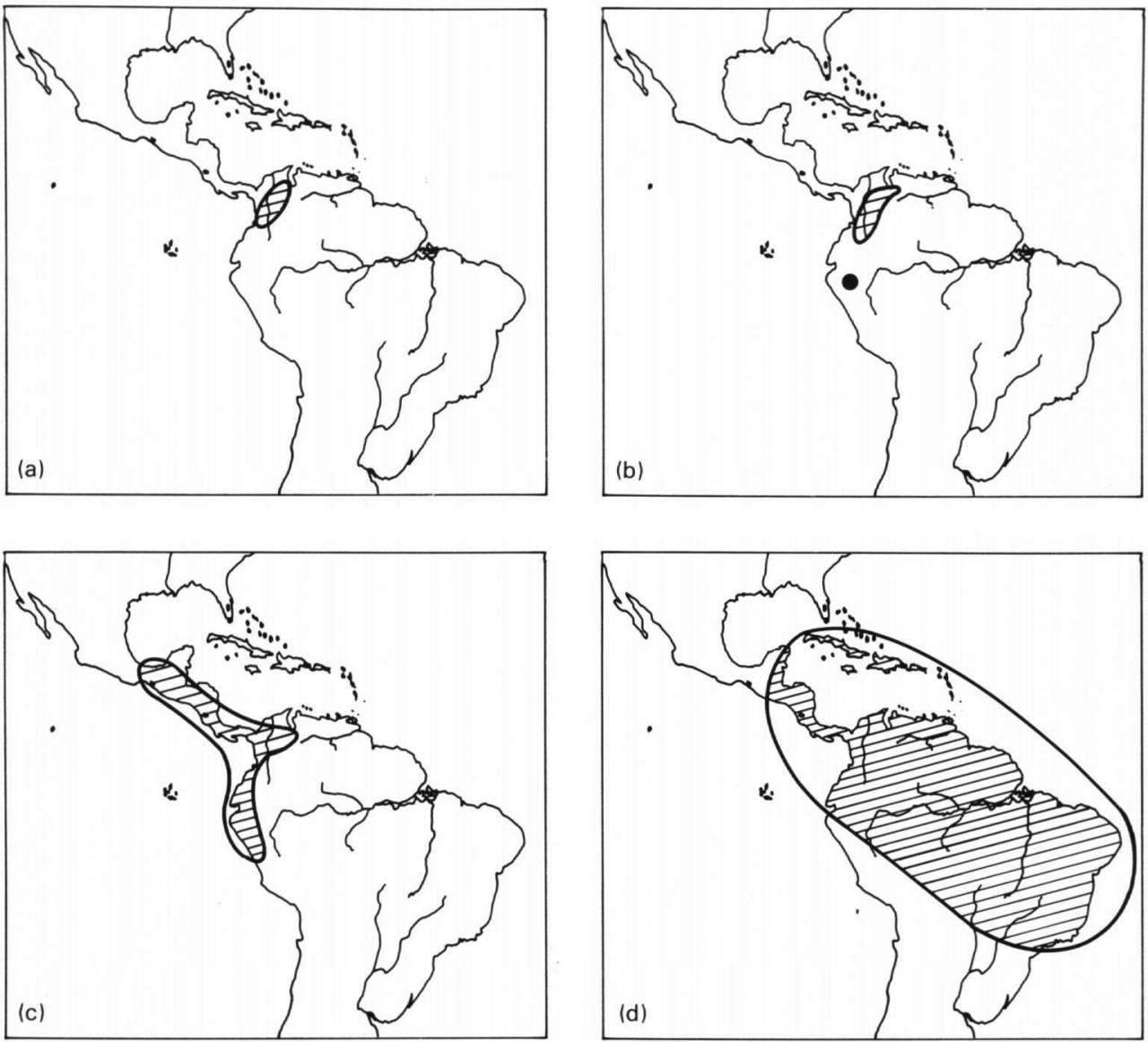

Fig. 4. Geographical elements in the Colombian bryophyte flora. (a) Endemic: Leptoscyphus cleefii Fulf.; in bogs and on moist soil in the páramo (fide colls. COL, U). (b) Endemic: Ruizanthus lopezii Schust.; on steep, shaded soil and rock in the páramo, along roadsides, etc. (Schuster 1985; Schultze-Motel \& Menzel 1987). (c) Andean: Campylopus pittieri Williams; terrestrial in páramos (Frahm 1988). (d) Neotropical: Symbiezidium barbiflorum (Gott.) Evans. Common epiphyte in lowland and submontane forests (Gradstein \& van Beek 1985).

palmata, Ruizanthus lopezii (Fig. 4b), Leptoscyphus cleefii (Fig. 4a), Anastrophyllum stellatum, Jungermannia ovato-trigona, Lindigianthus cipaconeus, Amphilejeunea viri- 
dissima and Colura ornithocephala among the liverworts; Fissidens wallisii, Leiomela ecuadorensis and Daltonia pulvinata among the mosses.

2. Andean element (Fig. 4c). Includes species ranging from Central America through the tropical Andes southwards to Bolivia, but lacking in other neotropical mountains. Many species have this type of distribution.

3. Neotropical element (Fig. 4d). Occurring throughout the neotropical region, in the lowlands and/or in the mountains, and sometimes ranging northwards into North America (e.g. Ctenidium malacodes). Many species fall in this category.

4. Wide tropical element (Fig. Sa). Occurring in the neotropics and in the palaeotropics. Some species are in the palaeotropics restricted to Africa, e.g. Lophocolea martiana (Gradstein et al. 1983), others are more widespread and also occur in Asia, e.g. Calymperes palisotii (Fig. 5a). A few may range into the warm-temperate portions of the northern and/or the southern hemisphere, e.g. Telaranea nematodes, Isopterygium tenerum. Recent work has revealed the existence of many wide tropical species (Frahm 1982; Gradstein 1987; Reese 1987, 1988) and it is expected that among the species presently assigned to the andean and the neotropical element several will eventually be shown to occur in the palaeotropics as well.

5. Temperate element (Fig. 5). The temperate element includes species that have their greatest expansion and frequency of occurrence in the temperature regions of the northern or southern hemisphere and probably originated there. Presumably they migrated to the Northern Andes in the late Tertiary or the Quaternary after the upheaval of the cordilleras. Three categories of temperate species may be distinguished:

(a) South temperate species (Fig. 5b). A list of the Colombian species (17 mosses, nine liverworts) belonging to this element was given by Cleef (1978) and Griffin et al. (1982);

(b) North temperate species (Fig. 5c). Fourteen Colombian liverworts fall in this category (Gradstein and Vána 1987); and

(c) Wide temperate species (Fig. 5d). This category contains mainly mosses, e.g. Racomitrium lanuginosum (Fig. 5d), Sphagnum magellanicum and S. recurvum; a liverwort falling in this category is Lophocolea bidentata. Cosmopolitic species such as Bryum argenteum and Polytrichum juniperinum also fall in this category.

Since the three temperate categories are each represented in the TPN transect by only a few species, they have been lumped into one single temperate element in the analysis.

The distribution of the geographical elements along the TPN transect is shown in Fig. 6. It appears that the understories of the submontane and lower montane forests, below $3000 \mathrm{~m}$, are largerly made-up of wide-ranging tropical (neotropical or wide tropical) species. They form $80 \%$ or more of the entire bryophyte flora. Below $1000 \mathrm{~m}$ all bryophyte species belong to this category. Above $3000 \mathrm{~m}$, in the upper montane zone and the páramo, the number of wide-ranging tropical species decreases to about $50 \%$ or less and narrow-ranging tropical species (endemic, Andean) become more common, attaining $30-45 \%$. The remaining species are of temperate origin.

Most of the narrow-ranging species belong to the andean element. Endemism is low among the bryophytes and is somewhat more common among liverworts than mosses. The low rate of endemism is probably due to the young age of the Andes and the slow evolution and good dispersal capacity of bryophytes (Van Zanten \& Gradstein 1988). Highest rates of endemism are found in Plagiochila (six endemic species) and Riccardia (three endemic species). We assume that some of these endemic species may eventually prove to be more widespread. The data clearly indicate that at lower altitudes (below $3000 \mathrm{~m}$ ) the Andean bryophyte flora consists almost exclusively of tropical species. 

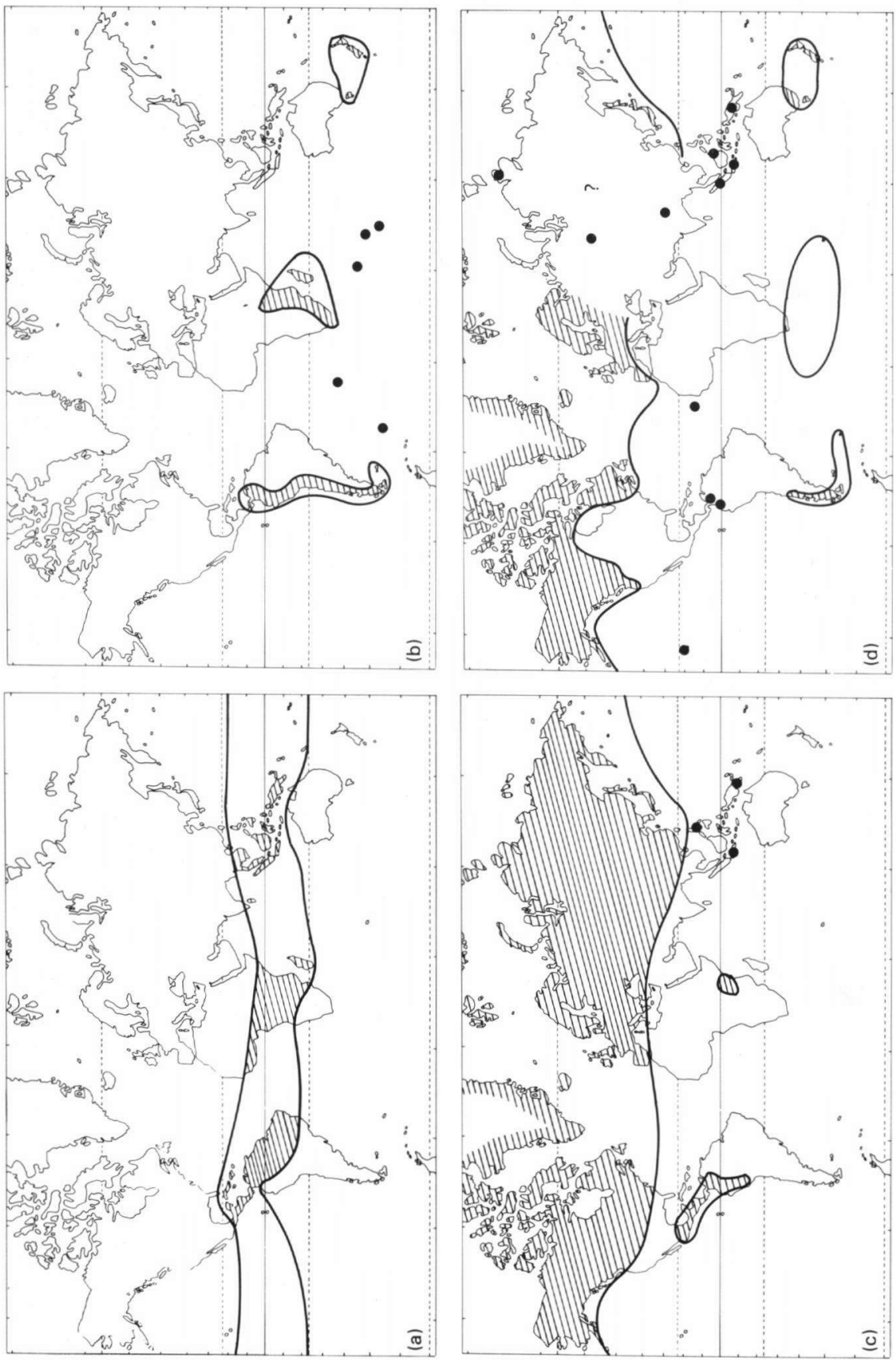

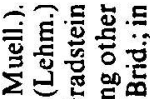
j.心 $\because$ \& \&

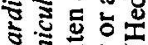

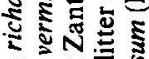

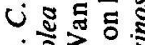
ن ปั 菏志元 必焉.논 运包它

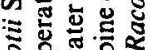
ह ํํㅇ क्ष 도을 行害兘 응 율 융

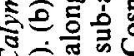
Uิ

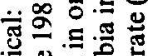

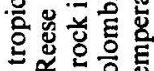
บ

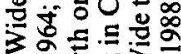

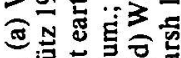

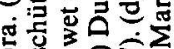
응 잉ㅎㅇ 논

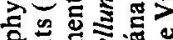

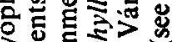
등ㅇㅇㅇ

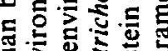

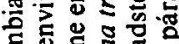
응응 흥 U 矛施 르을 홍 눵 E 品产语 응흥 원 至产这壳

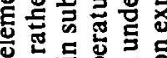
.

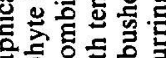
동응 릉. 웡 设

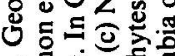
v 본 


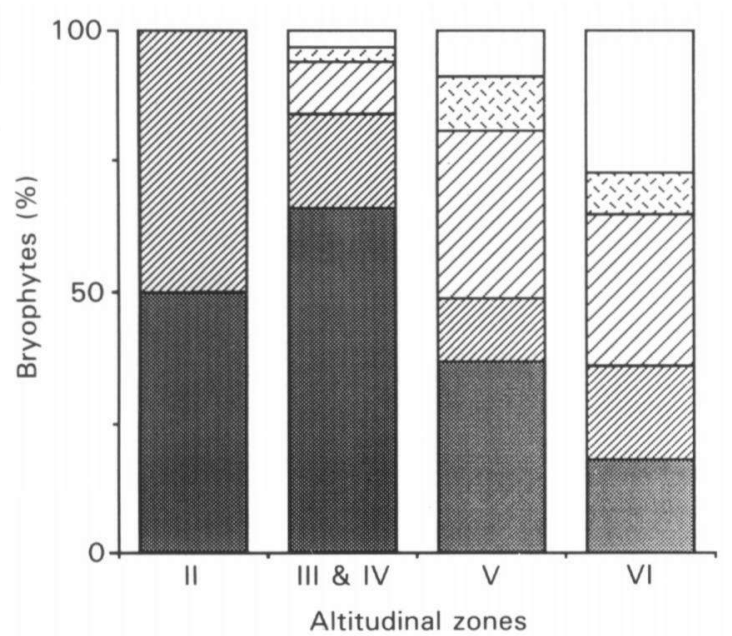

Fig. 6. Distribution of the bryogeographical elements in relation to the altitudinal bryophyte zones along the TPN transect. (口) Temperate; (四) endemic; ( $\square$ ) Andean; ( 6 ) wide tropical; (圈) neotropical.

Temperate species appear at higher altitudes and their number remains rather low: less than $10 \%$ in the upper montane forest and about $20 \%$ in the páramo.

It has been noted for vascular plants that temperate taxa may be more common in azonal than in zonal habitats (Cleef 1979; van der Hammen \& Cleef 1986). To test the validity of this observation for bryophytes a rough comparison was made between bryophyte species collected in the TPN plots and those recorded outside the plots in azonal habitats. The preliminary data indicate that in azonal vegetation the number of temperate species is not significantly higher, but their biomass may be larger. Thus temperate species were found to abound in peat bogs (Sphagnum spp.), on rock outcrops (Grimmiaceae), in mires (Amblystegiaceae), on road sides (Polytrichum juniperinum, Lophozia incisa, Jungermannia sphaerocarpa) and on rocks in streams (Brachythecium plumosum. Schistidium rivulare). The frequency of some of these species as colonizers in man-made habitats (road sides) indicates that they invaded the Andes in recent times due to human interference (Gradstein \& Vána 1987). These findings seem to corroborate vascular plant data and suggest that a more detailed comparison of the flora of zonal and azonal habitats might be worthwhile for a better understanding of the origin of the high Andean bryophyte flora.

In conclusion, it appears that the vast majority of the Andean bryophyte species are of tropical origin. They probably arrived from lower altitudes during the upheaval of the cordilleras. Temperate species are rather few and occur almost exclusively above $3000 \mathrm{~m}$. They should have arrived after the upheaval of the cordilleras and some may have invaded in recent, Holocenic times due to man-made disturbance of the environment. The bryophyte data presented here, although still incomplete, are documents of an interesting story of plant migration during the past 5 million years.

\section{ACKNOWLEDGEMENTS}

We are indebted to Dr Jan-Peter Frahm and Dr Hiroshi Inoue for checking the geographical ranges of some of the species (Dicranaceae, Plagiochilaceae) included in the analysis. 


\section{REFERENCES}

Allen, B.H. (1987): A revision of the genus Leucomium (Leucomiaceae). Mem. N.Y. Bot. Gdn, 45: 661-667.

Churchill, S.P. \& Hollaender, N. (1988): Bryologia Novo Granatensis. Estudios de los flora de musgos de Colombia III. Catálogo de musgos del Departamento del Valle. Bryologist, 9: 334-340.

Cleef, A.M. (1978): Characteristics of neotropical páramo vegetation and its subantarctic relations. Erdwiss. Forsch. 11: 365-390.

- (1979): The phytogeographical position of the neotropical vascular páramo flora, with special reference to the Colombian Cordillera Central. In: Larsen, K. and Holm-Nielsen, L.B. (eds): Tropical Botany. 175-184. Academic Press, London.

Cuatrecasas, J. (1958): Aspectos de la vegetación natural de Colombia. Revta Acad. Colomb. Cienc. Exact. Fis. Nat. 10: 40.

Engel, J.J. (1980): A monograph of the genus Clasmatocolea. Fieldiana (Bot.) N.S. 3: 1-229.

Florschütz, P. (1964): The mosses of Suriname. In: Lanjouw, J. (ed.): Flora of Suriname. VI: 1-271. Brill, Leiden.

Florschütz-de Waard, J. \& Florschütz, P.A. (1979): Lista comentada de los musgos de Colombia. Bryologist, 82: 215-259.

Frahm, J.-P. (1982): Grossdisjunktionen von Arealen südamerikanischer und afrikanischer CampylopusArten. Lindbergia, 8: 45-52.

- (1988): The subantarctic and southern hemispheric species of Campylopus (Dicranaceae), with contributions to the origin and speciation of the genus. J. Hattori Bot. Lab. 64: 367-387.

Frantzen, N.M.L.H.F.\& Bouman, F. (1989): Disposal and growth form patterns of some zonal páramo vegetation types. Acta Bot. Neerl. 38: 449-465.

Gentry, A.H. (1982): Neotropical floristic diversity: phytogeographical connections between Central and South America. Pleistocene climatic fluctuations, or an accident of the Andean orogeny? Ann. Mo. Bot. Gdn, 69: 557-593.

Gradstein, S.R. (1987): The Ptychanthoideae of Latin America: an overview. Bryologist, 90: 337-343.

- \& van Beek, J. (1985): A revision of the genus Symbiezidium Trevis. Beih. Nova Hedwigia, 80: 221-248.

- \& Frahm, J.-P. (1987): Die floristische Höhengliederung der Moose entlang des BRYOTROPTransektes in NO-Peru. Beih. Nova Hedwigia, 88: 105-113.

- \& Hekking, W.H.A. (1979): A catalogue of the Hepaticae of Colombia. J. Hattori Bot. Lab. 49: 93-144.

- \& Pócs, T. (1989): Bryophytes. In: Lieth, H. and Werger, M.J.A. (eds): The Tropical Rain Forest, Ecosystems of the World. 14B: 311-325. Elsevier, Amsterdam.
—, Pócs, T. \& Vána, J. (1983): Disjunct Hepaticae in tropical America and Africa. Acta Bot. Hung. 29: 127-171.

— \& Vána, J. (1987): On the occurrence of Laurasian liverworts in the Tropics. Mem. N.Y. Bot. Gdn 45: 388-425.

Griffin, D. \& Gradstein, S.R. (1981): Bryological exploration of the tropical Andes: current status. Beih. Nova Hedwigia, 71: 513-518.

-, - \& Aguirre, C. (1982): Studies on Colombian Cryptogams XVII. On a new antipodal element in the neotropical páramos-Dendrocrypheae latifolia sp. nov. (Musci). Acta Bot. Neerl. 31: 175-184.

Grolle, R. (1988): Miscellanea Hepaticologica 261270. J. Hattori Bot. Lab. 65: 403-410.

van der Hammen, T. \& Cleef, A.M. (1986): Development of the high Andean páramo flora and vegetation. In: Vuilleumier, $\mathbf{F}$. and Monasterio, $M$. (eds): High Altitude Tropical Biogeography. 153200. Oxford University Press, Oxford.

—, Preciado, A.P. \& Pinto, P. (1983): La Cordillera Central Colombiana, Transecto Parque los Nevados (introduccion y datos iniciales). Studies on Tropical Andean Ecosystems. 1: 1-345.

-\& Ruiz, P.M. (1984): La Sierra Nevade de Santa Marta (Colombia), Transecto Buritaca-La Cumbre. Studies on Tropical Andean Ecosystems. 2: $1-603$.

Linares, E.L. (1986): Estudio taxonomico y ecologico de la brioflora en la franja alto-andina de 'El Tablazo', Cundinamarca. Trabajo de Grado, Universidad Nacional de Colombia, Departamento de Biologia. 1-308.

Reese, W.D. (1987): Calymperes (Musci: Calymperaceae): world ranges, implications for patterns of historical dispersion and speciation, and comments on phylogeny. Brittonia, 39: 225-237.

- (1988): World ranges, implications for patterns of historical dispersal and speciation, and comments on phylogeny of Syrrhopodon (Calymperaceae). Mem. N.Y. Bot. Gdn, 45: 426-445.

Sastre-de Jesús, I., Churchill, S.P. \& Escobar, M. (1986): Catálogo de musgós del Departamento de Antioquia, Colombia. Actual. Biol. 15: 77-94.

Schultze-Motel, W. \& Menzel, M. (1987): Die Lebermoosflora im BRYOTROP-Transektes in NO-Peru. Beih. Nova Hedwigia, 88: 61-104.

Schuster, R.M. (1985): Studies on Venezuelan Hepaticae III. Families Blepharostomataceae and Balantiopsidaceae. Nova Hedwigia, 42: 49-79.

Van Reenen, G.B.A. (1983): Distribucion y ecologia de musgos y hepaticas (datos iniciales). Studies on Tropical Andean Ecosystems. 1: 206-209.

- (1987): Altitudinal bryophyte zonation in the Andes of Colombia: a preliminary report. Symp. Biol. Hung. 35: 631-637. 
- \& Gradstein, S.R. (1983): Studies on Colombian Cryptogams XX. A transect analysis of the bryophyte vegetation along an altitudinal gradient on the Sierra Nevada de Santa Marta, Colombia. Acta Bot. Neerl. 32: 163-175.

- \& - (1984): An investigation of bryophyte distribution and ecology along an altitudinal gradient in the Andes of Colombia. J. Hattori Bot. Lab. 56: 79-84.

—, Griffin, D. \& Gradstein, S.R. (1984): Briófitos del transecto Buritaca-La Cumbre, Sierra Nevada de Santa Marta, Colombia. Studies on Tropical Andean Ecosystems. 2: 177-183.
Van Zanten, B.O. \& Gradstein, S.R. (1988): Experimental dispersal geography of neotropical liverworts. Beih. Nova Hedwigia, 90: 41-94.

Vitt, D.H. \& Marsh, C. (1988): Population variation and phytogeography of Racomitrium lanuginosum and $R$. pruinosum. Beih. Nova Hedwigia, 90: 235260.

Wolf, J.H.D. (1989): Comunidades epíftas en un transecto altitudinal en la Cordillera Central, Colombia (La quantidad de especies de briófitas y liquenes). Studies on Tropical Andean Ecosystems. 3. 